\title{
Factors determining variations in otolith microincrement width of demersal juvenile Baltic cod Gadus morhua
}

\author{
K. Hüssy ${ }^{1, *}$, H. Mosegaard ${ }^{1}$, H.-H. Hinrichsen ${ }^{2}$, U. Böttcher ${ }^{3}$ \\ ${ }^{1}$ Danish Institute for Fisheries Research, Charlottenlund Castle, 2920 Charlottenlund, Denmark \\ ${ }^{2}$ Dept. Fishery Biology, Institute for Marine Research, University of Kiel, Düstenbrooker Weg 20, 24105 Kiel, Germany \\ ${ }^{3}$ Institute for Baltic Sea Fisheries, An der Jägerbäk 2, 18069 Rostock, Germany
}

\begin{abstract}
Pelagic and demersal juvenile Baltic cod Gadus morhua L. were collected on the slope and the top of Rønne bank in the Baltic Sea during 2 cruises in November and December 1998. The objective of this study was to evaluate distinct changes in otolith increment width observed in demersal juveniles by comparison with laboratory-reared individuals, and to investigate the factors determining variation in these increments. The different increment-width patterns were identified with a method based on the widths of consecutive increments. Otolith increment widths of juvenile cod were found to be highly variable within and between individuals, in both the experimental and the field samples. The first change in increment pattern observed in the field samples was related to settling. The formation periodicity of increments within the different pattern intervals was confirmed with a growth model based on otolith growth rates of juvenile cod reared in the laboratory under different conditions. In this model, otolith growth rate was expressed as a function of rearing temperature and fish dry weight. Otolith growth of the field samples was calculated using ambient temperatures obtained from a 3D-circulation model. The best fit to observed otolith growth rates was obtained under the assumption that fish on the slope performed daily vertical migrations between the warm surface layer and the cold bottom layer. The data suggested that fish stayed in the surface layer during the first increment-pattern interval, performed vertical migrations during the second interval, and stayed in association with the seafloor in the subsequent interval, corresponding to the time after the breakdown of the thermocline.
\end{abstract}

KEY WORDS: Otolith microstructure $\cdot$ Daily increments $\cdot$ Juvenile cod $\cdot$ Baltic Sea Resale or republication not permitted without written consent of the publisher

\section{INTRODUCTION}

In the Baltic Sea, newly settled Baltic cod Gadus morhua L. are predominantly found in nearshore areas down to a water depth of 60 to $80 \mathrm{~m}$ (Nielsen et al. 1997, Böttcher et al. 1998). These habitats may be very heterogeneous, particularly with respect to thermal stratification. The hydrography of the Baltic is governed by freshwater input from river runoff and saltwater inflows from the North Sea (Matthäus \& Franck 1992), resulting in a permanent pycnocline at 60 to $80 \mathrm{~m}$, with a temperature of $\sim 4^{\circ} \mathrm{C}$ in the deep water (Gidhagen 1987). Above the pycnocline, a seasonal thermocline develops in spring at around $30 \mathrm{~m}$ depth and remains stable until late autumn, with summer surface temperatures up to $18^{\circ} \mathrm{C}$ (Gidhagen 1987).

During their pelagic stage, juvenile cod make excursions to the seafloor, and following settling perform extensive vertical migrations into the water column (Böttcher \& Oeberst 1996, Nielsen et al. 1997, Böttcher et al. 1998). The combined effects of stratified environment and vertical migration may influence the otolith microstructure of these juvenile fish.

After Pannella's (1971) discovery of otolith microincrements that appeared to be formed on a daily basis, great effort was directed towards the validation 
of daily increment formation. A wide range of factors may affect increment formation. Constant light or darkness either has no effect on increment formation periodicity (Campana \& Neilson 1982, Geffen 1982, Neilson \& Geen 1982) or inhibits visible structure (Taubert \& Coble 1977, Radtke \& Dean 1982). However, changes in light intensity trigger the formation of increments (Tanaka et al. 1981), which promoted the hypothesis that the photoperiod does not affect increment formation periodicity but acts as a zeitgeber in an endogenously controlled circadian formation cycle (Campana \& Neilson 1985). Food level does not appear to affect increment formation periodicity (Marshall \& Parker 1982, Campana 1983a, Neilson \& Geen 1985). A decrease in increment formation rate at low rations (Geffen 1982) may be an artefact caused by increment widths smaller than the resolution limit of the light microscope used (Campana et al. 1987). At constant temperatures, increments are formed daily, regardless of temperature (Neilson \& Geen 1982, Radtke \& Dean 1982), but only within the range of temperatures that allow positive somatic growth (Taubert \& Coble 1977 , Campana \& Neilson 1982, Marshall \& Parker 1982, Radtke \& Dean 1982). Temperature effects on otolith increment-formation rate may also be an artefact caused by the resolution limit of the light microscope. Variations in temperature, on the other hand, result in a disruption of the formation period (Brothers 1981), and Neilson \& Geen (1985) demonstrated the formation of 2 increments per $24 \mathrm{~h}$ at a temperature cycle of $12 \mathrm{~h}$.

In homogenous water masses, temperature dependence of otolith increment formation does not pose a problem for the ageing of fish. However, in a heterogeneous environment like the settling habitat of Baltic cod, juvenile fish may experience large variations in temperature as a result of their daily vertical migrations. Previous studies have reported difficulties with age determination of juvenile Baltic cod (e.g. Steffensen 1980, Linkowsky \& Kowalewska-Pahlke 1993, Böttcher \& Oeberst 1996). Observed increments may not be daily and the resulting age estimates may be biased.

During the settling process on the slope of the Bornholm Basin, Denmark, fish are exposed to temperature changes when they migrate across the thermocline. Such temperature effects may overrule the formation of daily increments (Campana 1983b, Neilson \& Geen 1985), resulting in pronounced subdaily increments. The main objective of this study was therefore to evaluate whether the increments observed in juvenile Baltic cod otoliths were formed on a daily basis. An otolith growth model was developed, where otolith weight-increase corresponding to individual increments was investigated in relation to different environ- mental conditions. The parameters of this model were estimated in laboratory experiments with juvenile cod subjected to different rearing conditions after validation of daily increment formation in these fish. The hypothesis of daily increment formation in juvenile Baltic cod was addressed by comparison of otolith increment growth rates observed in field samples with model-derived estimates of these increments. Other objectives were to evaluate changes in increment pattern observed in field samples and the formation periodicity within the pelagic and demersal stages in relation to vertical migration behaviour.

\section{MATERIALS AND METHODS}

The validation of daily increment formation in field samples of Baltic cod is based on an otolith growth model developed from juvenile cod reared under different conditions in the laboratory. The daily formation of otolith increments in these samples was validated by comparison of observed increment numbers with known age. From these experimental samples, a model was developed, relating otolith weight increase to different variables. A method was developed to identify intervals with similar increment structure in otoliths of juvenile Baltic cod field samples. The daily periodicity of increment growth observed within these intervals was then validated using the model developed from the experimental samples.

Experimental samples. A total of 500 juvenile Atlantic cod, offspring of 2 females and 2 males, were obtained from the Isle of Man Marine Laboratory, University of Liverpool, British Isles, at an age of $60 \mathrm{~d}$ and approximately $20 \pm 3.49 \mathrm{~mm}$ standard length (SL, average $\pm \mathrm{SD}$ ). After $7 \mathrm{~d}$ of acclimatisation at $12^{\circ} \mathrm{C}$ at the Danish Institute for Fisheries Research, a temperature mark was induced in the otoliths of the fish by alternating the water temperature between 6 and $12^{\circ} \mathrm{C}$, with 3 periods of $3 \mathrm{~h}$ exposure to $12^{\circ} \mathrm{C}$ followed by $1 \mathrm{~h}$ exposure to $6^{\circ} \mathrm{C}$. After $12 \mathrm{~h}$ at $12^{\circ} \mathrm{C}$, this temperature cycle was repeated, resulting in a clearly visible increment pattern (Fig. 1).

The fish were measured and weighed to the nearest $0.5 \mathrm{~mm}$ and $0.01 \mathrm{~g}$. They were kept in $32 \%$ seawater at full aeration and a light cycle of 16:8 h light:dark, and fed a diet of dry food pellets (Perla Marine). Three temperature treatments were maintained, $4.9 \pm 0.4,10.1 \pm$ 1.2 and $15.1 \pm 0.6^{\circ} \mathrm{C}$, and monitored daily by a Tinytag temperature logger. Two food levels were provided: ad libitum feeding (approximately 4.0, 5.5 and $7.5 \%$ of fish dry weight per day for 5,10 and $15^{\circ} \mathrm{C}$ respectively) and approximately $65 \%$ of ad libitum level. These 2 feed levels are referred to as high and low, respectively. Food was provided continually by automatic 


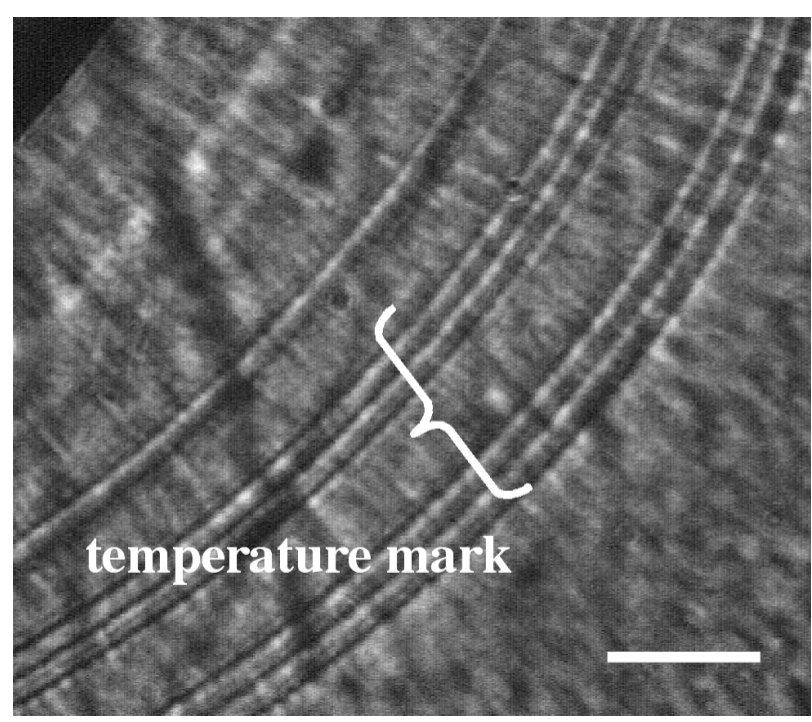

Fig. 1. Gadus morhua. Otolith of experimental fish with temperature mark $($ scale bar $=15 \mu \mathrm{m})$

feeders during daylight hours. At Days 0, 10, 20, 30 and 40 all fish were anaesthetised with MS 222, measured and weighed, and a random subsample of 10 fish from each treatment was killed. The remaining 150 fish were used in other experiments. No other mortalities occurred during the experiment. Sagittal otoliths, hereafter referred to as otoliths, were extracted, rinsed in water and stored in labelled plastic bags.

Otolith treatment. All otoliths were weighed to the nearest $\mu g$ (otolith weight: OW), mounted on microscope slides with thermoplastic cement (Büehler) with the proximal side facing up, ground to the central plane on a rotating disc covered with grinding paper (grit 1200; M3), and polished on grinding paper $(3 \mu \mathrm{m})$ and with aluminium oxide paste (Büehler, $0.05 \mu \mathrm{m}$ ). They were then turned, ground to a uniform thickness of about $80 \mu \mathrm{m}$ and polished again.

For the analysis of otolith microstructure, an image analysis system (IMAGE PRO, Version 4) was used with a microscope coupled to a monitor screen by a CCD camera and a frame grabber. Images were digitised and saved as TIFF-files in black and white. Total otolith length (OL) was measured along the longest distance from the nucleus to the tip of the rostrum. Increment widths $\left(\mathrm{IW}_{\mathrm{i}}\right)$, counting from the temperature mark, were measured along a profile of grey values (from $0=$ black to $255=$ pure white, band width = $50 \mu \mathrm{m})$ with the 'caliper' tool of Image Pro at a magnification corresponding to $2.2 \mu \mathrm{m}$ pixel $^{-1}$. The start of an increment was defined as a rising point of inflection calculated from the divergence of the individual pixel's grey value from the running average. Measurements taken at a slightly different angle were scaled to OL.
The number of increments found with this method were tested against the known number of days in the time intervals used.

Otolith growth model. The relationship between OL and OW of the pooled experimental samples is described by the model:

$$
\ln (\mathrm{OW})=a_{\mathrm{OL}}+b_{\mathrm{OL}} \cdot \ln (\mathrm{OL})+\varepsilon_{\mathrm{OW}}
$$

where OW = otolith weight in $\mathrm{mg}, \mathrm{OL}=$ otolith length in $\mu \mathrm{m}, \varepsilon_{\mathrm{OW}}=$ error of the individual, and $a$ and $b$ are model parameters.

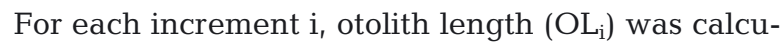
lated and the corresponding OW estimated as:

$$
\mathrm{OW}_{\mathrm{i}}=\exp \left\{a_{\mathrm{OL}}+\left[\ln (\mathrm{OL})-a_{\mathrm{OL}}\right]\right\} \cdot\left[\ln \left(\mathrm{OL}_{\mathrm{i}}-\mathrm{OL}\right)\right]
$$

where $\mathrm{OW}_{\mathrm{i}}=$ otolith weight at increment $\mathrm{i}, \mathrm{OL}=$ otolith length at death, and $\mathrm{OL}_{\mathrm{i}}=$ otolith length at increment i. OW change per day was calculated as $\Delta \mathrm{OW} / \Delta t_{\mathrm{i}}=$ $\mathrm{OW}_{\mathrm{i}}-\mathrm{OW}_{\mathrm{i}-1}$.

Explaining variation in fish size by size-dependent growth alone has been shown to fail (Imsland et al. 1998). For the back-calculation of fish dry weight at previous time steps, this parameter was therefore not considered. For all treatments, fish dry weight at previous time steps was analysed using general linear models (GLMs) and was best described by the model:

$\ln \left(\mathrm{DW}_{\mathrm{i}}\right)=$

$a_{\mathrm{DW}}+b_{\mathrm{DW}} \cdot \ln \left(T_{\mathrm{i}}\right)+c_{\mathrm{DW}} \cdot$ day $+d_{\mathrm{DW}} \cdot$ ration $+\varepsilon_{\text {ind }}$

where $\mathrm{DW}_{d}=$ fish dry weight in g on Day $d, T=$ actual temperature in ${ }^{\circ} \mathrm{C}$ on Day $d$, day $=$ day of the experiment, ration $=$ food level, where ad libitum was assigned a value of 100 and low ration a value of 65 , and $\varepsilon_{\text {ind }}=$ model error. Dry weights of all fish were estimated for each day of the experiment using Model (3).

The effect of otolith size and temperature on otolith growth over the experimental period was then also tested using a GLM. Since all cod juveniles and otoliths had roughly the same start size, these variables were not included. The model that described the data best was:

$$
\begin{aligned}
& \ln \left(\Delta \mathrm{OW}_{\mathrm{i}} / \Delta t_{\mathrm{i}}\right)= \\
& a_{\mathrm{OW}}+b_{\mathrm{OW}} \cdot \ln \left(\mathrm{DW}_{\mathrm{i}}\right)+c_{\mathrm{OW}} \cdot \ln \left(T_{\mathrm{i}}\right)+\varepsilon_{\mathrm{mod}}
\end{aligned}
$$

Field samples. A total of 82 pelagic juvenile Baltic cod were collected with RV 'Solea' on Days of Year 305 to 307 (from 3 to 5 November) with an Isaac-Kidd midwater trawl towed at a speed of 4 knots (Fig. 2). A subsample of 20 fish was selected. Demersal juvenile Baltic cod were collected with RV 'Dana' in 2 main areas of interest in the same region: on 8 December, 169 fish were caught in a shallow area on Oder bank $\left(54^{\circ} 41^{\prime} 30^{\prime \prime} \mathrm{N}\right.$, $14^{\circ} 31^{\prime} 30^{\prime \prime} \mathrm{E}$, bottom depth $27 \mathrm{~m}$ ) and 105 fish were caught in a deeper area on the slope of the Bornholm Basin ( $54^{\circ} 33^{\prime} 30^{\prime \prime} \mathrm{N}, 15^{\circ} 22^{\prime} 80^{\prime \prime} \mathrm{E}$, bottom depth $47 \mathrm{~m}$ ) in 


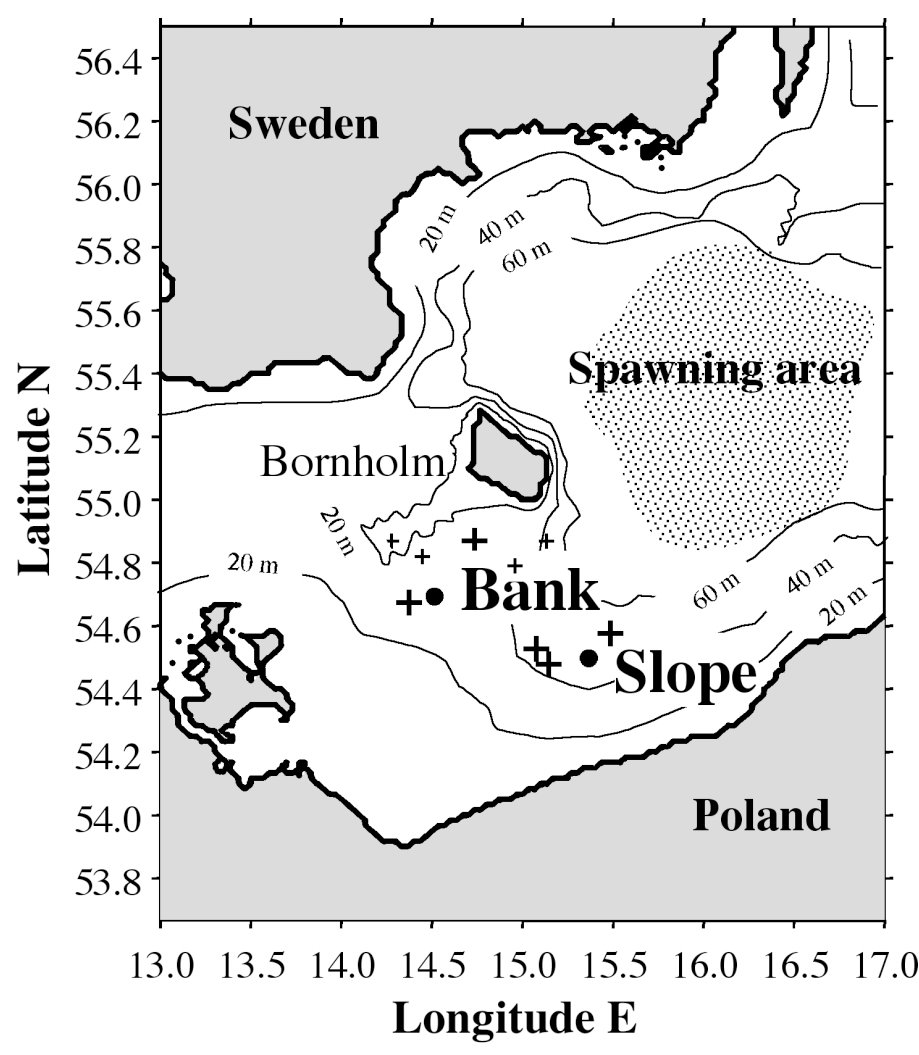

Fig. 2. Map of the Baltic Sea, with sampling stations from the 2 cruises. -: December RV 'Dana' cruise marked as 'Slope' and 'Bank'; +: November RV 'Solea' cruise, where large symbols signify $>2$ fish, small symbols $=2$ fish. Axis units in decimal numbers

a Grande Ouverture (GOV) bottom trawl towed at a speed of 4 knots (Fig. 2). For analysis, a random subsample of 50 fish was selected from each area.

After capture, the fish were immediately frozen at $-20^{\circ} \mathrm{C}$. In the laboratory fish were thawed, SL measured to the nearest $0.5 \mathrm{~mm}$, dried at $60^{\circ} \mathrm{C}$ for $48 \mathrm{~h}$ and weighed (DW) to the nearest $0.01 \mathrm{~g}$. Otoliths were treated like the experimental samples, and IW $_{\mathrm{i}}$ counted and measured from the accessory primordia to the edge of the otolith.

Increment structure in the field samples. In the field samples, drastic changes in $\mathrm{IW}_{\mathrm{i}}$ were observed, particularly in otoliths from the slope. Examples of IW $_{\mathrm{i}}$ patterns representative for fish from the slope and the bank are shown in Fig. 3, with interval patterns indicated by vertical lines. To identify the timing of these changes in increment pattern, as well as the magnitude of the change objectively, we developed a method based on the width of consecutive $I_{\mathrm{i}}$.

The difference between the running average of the 10 previous and the 10 following increments was calculated for every increment: $D_{\mathrm{i}}=$ absolute value of
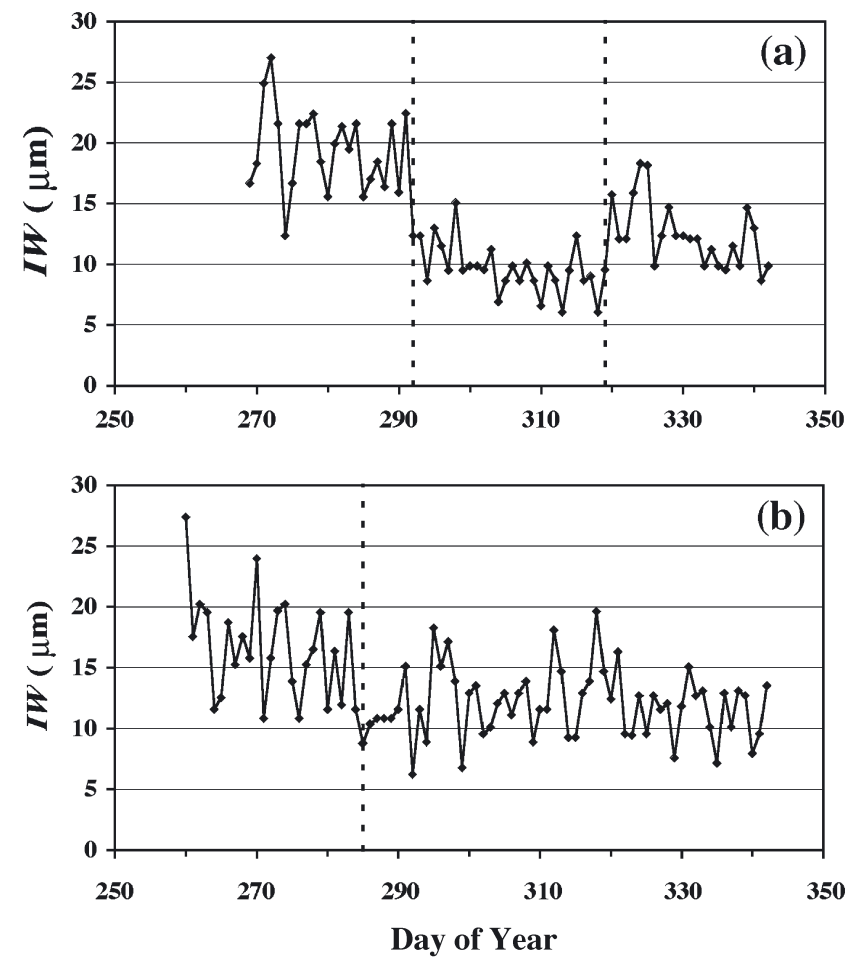

Fig. 3. Gadus morhua. Examples of otolith increment width (IW) development over time of juvenile cod caught on (a) slope and (b) bank. Vertical broken lines indicate change in increment width pattern

average $\left(I_{i-10}\right.$ to $\left.I W_{i}\right)$ - average $\left(I_{i}\right.$ to $\left.I W_{i+10}\right)$. For the 5 to 10 first and last increments, values were calculated by reducing the number of increments included in the running average. The 5 first and last increments were thus excluded from the analysis. $D_{\text {maxj }}$ were defined as the largest $D_{\mathrm{i}} \mathrm{s}$ where both $D_{\mathrm{i}-1}$ and $D_{\mathrm{i}+1}$ had smaller values. These $D_{\operatorname{maxj}}$ were achieved when increment widths change from one pattern to another and matched the visual observations well. $D_{\text {maxj }}$ were numbered from the accessory primordia outward, and the corresponding otolith lengths $\left(\mathrm{OL}_{\mathrm{j}}\right)$ were recorded. The corresponding otolith weights $\left(\mathrm{OW}_{\mathrm{j}}\right)$ were calculated using Model (2). Intervals of similar microstructure patterns $\left(I_{\mathrm{j}}\right)$ were numbered from the accessory primordia in the rostral axis and outward, so that $D_{\operatorname{maxj}}$ is the jth maximum observed at $\mathrm{OL}_{\mathrm{j}}$, the otolith length at the end of interval $I_{\mathrm{j}}$ (see overview of these terms in Fig. 4). Numbers of increments observed within the different pattern intervals $\left(n_{\mathrm{j}}\right)$ were counted. Otolith length and weight at accessory primordia were called $\mathrm{OL}_{0}$ and $\mathrm{OW}_{0}$.

Baltic Sea temperature data. Temperature is a key component in the models used to estimate otolith growth. Daily temperature profiles at the 2 localities were therefore estimated for each day using the 3D 


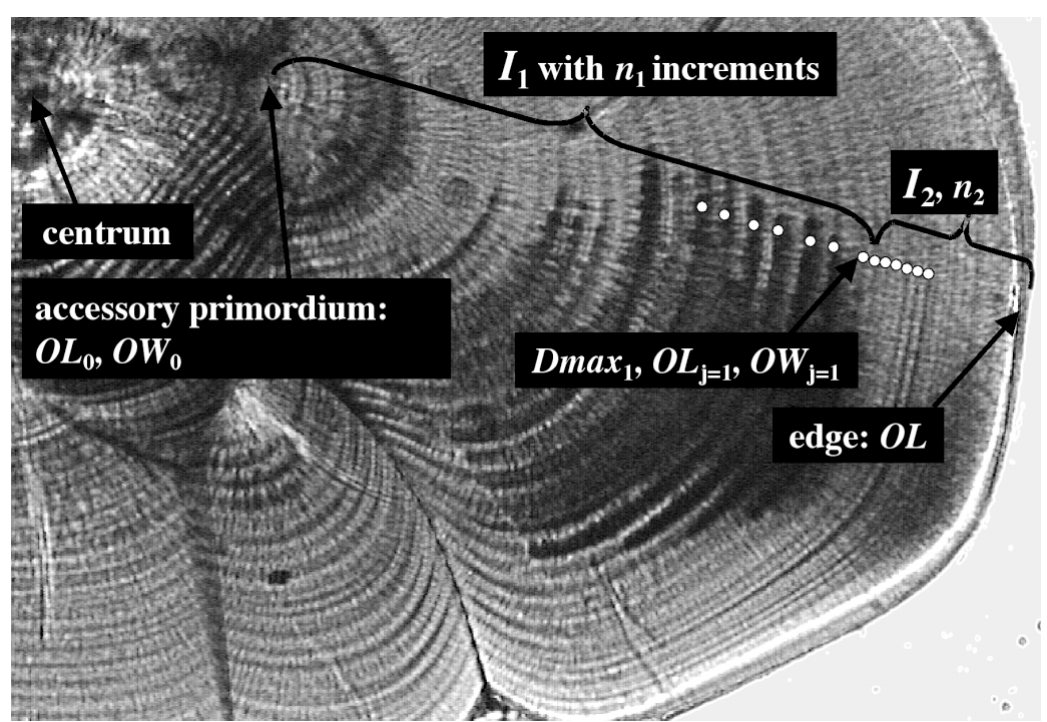

Fig. 4. Gadus morhua. Overview of measurements recorded and their abbreviations. centrum $=$ nucleus of the otolith; $\mathrm{OL}_{0}, \mathrm{OW}_{0}=$ otolith length and weight at formation of accessory primordia; $D_{\max 1}=$ maximum difference in average $\left(I_{W_{-10}}\right.$ to $\left.I W_{i}\right)$ - average $\left(I_{i}\right.$ to $\left.I W_{i+10}\right)$ denoting change in increment pattern $I_{1}, I_{2}=$ increment pattern intervals 1 and 2 , with corresponding number of increments $n_{1}, n_{2}$ and corresponding otolith length and weight $\mathrm{OL}_{1}$ and $\mathrm{OW}_{1}$. The 6 increments before and after the change in increment width pattern are indicated with white points throughout the year, with temperatures decreasing from approximately 14 to $4.5^{\circ} \mathrm{C}$ in the investigated time period (Fig. 5b). Data were not available from Day of Year 334 onward, but were extrapolated linearly to measured values from the December cruise.

Validation of daily increment formation in the field samples. For every increment-pattern interval of the field sample, an observed otolith growth rate was calculated as: $\Delta \mathrm{OW} / \mathrm{D} t_{\mathrm{j}}=$ $\left(\mathrm{OW}_{\mathrm{j}+1}-\mathrm{OW}_{\mathrm{j}}\right) / n_{\mathrm{j}}$. The experiment started $15 \mathrm{~d}$ after metamorphosis and the formation of accessory primordia, and Model (4) may thus not be valid for the period from metamorphosis to $15 \mathrm{~d}$ post metamorphosis. The increments of the field samples, on the other hand, were analysed back to the accessory primordia. Otolith growth rates of the field sample were therefore not estimated for the first $15 \mathrm{~d}$ after formation of the accessory primordia. eddy-resolving baroclinic model of the Baltic Sea (Lehmann 1995). This model was developed at the Institute for Marine Research in Kiel, Germany, and is based on the free-surface BryanCox-Semtner model, a modified version of the Cox numerical general ocean circulation model (Bryan 1969, Semtner 1974, Cox 1984). The model covers the whole Baltic, from the Kattegat and Skagerrak to the Gulfs of Riga and Bothnia. It has a horizontal resolution of $5 \mathrm{~km}$ with 41 vertical levels and a time-step of $5 \mathrm{~min}$. The model is forced by actual atmospheric data (wind, air temperature, humidity, etc.), provided by the Swedish Meteorological and Hydrological Institute and river runoff taken from a mean runoff database (Bergström \& Carlsson 1994), as well as field data obtained during research cruises. Model output values were averaged to obtain a $24 \mathrm{~h}$ resolution.

On the slope, a strong thermocline developed around Day of Year 120 (where Day 1 = January 1) at a depth of $35 \mathrm{~m}$, with $14^{\circ} \mathrm{C}$ at the surface and $5^{\circ} \mathrm{C}$ at the bottom and persisted approximately until Day of Year 290. After Day of Year 320, an inverse thermocline, with cold water above warmer bottom water, developed and persisted to the day of capture (Fig. 5a). On the bank, the water column was mixed virtually
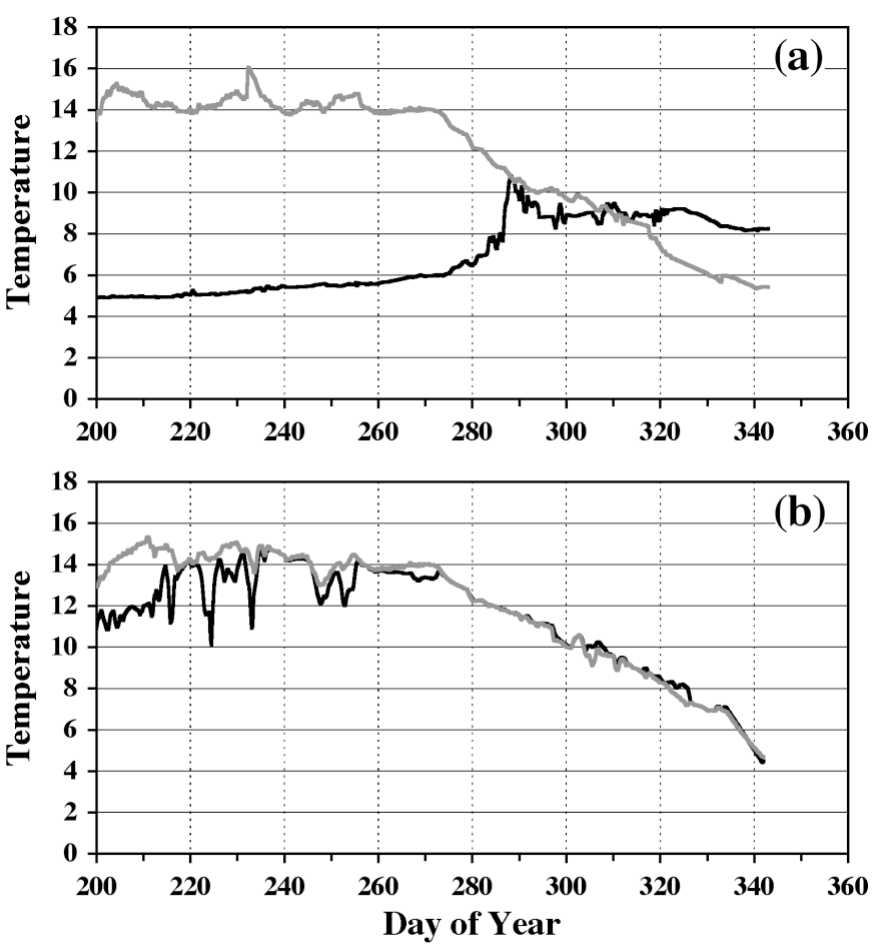

Fig. 5. Temperature in the surface layer and near the bottom of 2 localities on Rønne Bank, Baltic Sea: (a) slope and (b) bank. Black lines: $0.5 \mathrm{~m}$ above bottom, grey lines: $1.5 \mathrm{~m}$ below surface. In (b) temperatures after Day of Year 334 extrapolated to values observed on Day of Year 342 
For the same pattern intervals, expected otolith growth rates were calculated using Model (4). The DW-OW relationship of the pooled November and December samples was best described by the model: $\ln (\mathrm{DW})=a+b \cdot \ln (\mathrm{OW})+c \cdot \ln (\mathrm{OW})^{2}\left(\mathrm{r}^{2}=0.96, \mathrm{n}=120\right.$, where $a=-2.025, b=0.924, c=0.094)$. Assuming a proportional relationship between fish- and otolithsize over time, the DW variable of the field sample used in Model (4) was thus estimated as:

$$
\begin{aligned}
& \ln \left(\mathrm{DW}_{\mathrm{i}}\right)= \\
& \quad \ln \left(\mathrm{DW}_{\text {catch }}\right) \times \frac{a+b \cdot \ln \left(\mathrm{OW}_{\mathrm{i}}\right)+c \cdot \ln \left(\mathrm{OW}_{\mathrm{i}}\right)^{2}}{a+b \cdot \ln \left(\mathrm{OW}_{\mathrm{catch}}\right)+c \cdot \ln \left(\mathrm{OW}_{\mathrm{catch}}\right)^{2}}
\end{aligned}
$$

Newly settled juvenile cod are known to spend the day in close association with the seafloor, and migrate up into the water column at night (Perry \& Neilson 1988, Lough \& Potter 1993). The temperature input used in Model (4) was therefore modelled under 3 different scenarios: (1) juvenile cod stay above the thermocline, (2) juvenile cod stay close to the bottom throughout the day and night and (3) juvenile cod stay close to the bottom during the day and move up into the water column at night. The temperature experienced over $24 \mathrm{~h}$ by migrating fish was modelled as:

$T=\left[h_{\text {daylight }} \cdot T_{\text {bottom }}+\left(24-h_{\text {daylight }}\right) \cdot T_{\text {surface }}\right] / 24$

where $h_{\text {daylight }}=$ hours of day light from sunrise to sunset. Surface temperatures over time were very similar at the 2 localities and assumed to be representative of the whole surface mixed layer in which the fish drift from the spawning area in the Bornholm Basin to the capture site (see e.g. Lehmann 1995). Horizontal migrations were assumed not to occur.

Within the pattern intervals $I_{\mathrm{j}}$, the observed $\mathrm{OL}_{\mathrm{j}} \mathrm{S}$ were used as starting points and transformed to otolith weight $\mathrm{OW}_{\mathrm{j}}$ using Model (2). Otolith growth was estimated using Model (4) for as many days as the number of observed increments, $n_{\mathrm{j}}$, in $I_{\mathrm{j}}$. The estimated OW at the end of each interval $\mathrm{OW}_{\text {est } j+1}$ was recorded and otolith growth rates calculated as: $\Delta \mathrm{OW}_{\mathrm{est}} / \Delta t_{\mathrm{j}}=$ $\left(\mathrm{OW}_{\text {est } \mathrm{j}+1}-\mathrm{OW}_{\text {est } \mathrm{j}}\right) / n_{\mathrm{j}}$.

\section{RESULTS}

\section{Validation of daily increment formation in the experimental samples}

For all sampling dates, temperatures and ration levels individually, the slopes of the known age-observed increment-number regressions did not differ significantly from 1 (all p > 0.05, all $n=10$ ) and the intercepts did not differ significantly from zero (all $\mathrm{p}>0.05$, all $\mathrm{n}=10$ ). Neither slope nor intercept of the known ageobserved increment regression were affected by tem- perature (ANCOVA, $\mathrm{p}>0.05, \mathrm{n}=350$ ) and ration (ANCOVA, $\mathrm{p}>0.05, \mathrm{n}=350$ ). Increments were therefore assumed to be formed daily in the experimental samples.

\section{Otolith growth model}

The parameters of Models (1) to (4) were estimated from the experimental samples after validation of daily increment formation in these samples.

Models (1) and (2)

In the experimental samples, the parameters of Model (1) were estimated as $a_{\mathrm{OL}}=-16.309(0.240)$ and $b_{\mathrm{OL}}=$ $2.4197(0.035)$, where values in brackets are SEs of the estimate $\left(p<0.05, r^{2}=0.95, n=350\right)$. The model error $\varepsilon_{O W}$ was distributed normally with homogenous variance $\left(\mathrm{s}^{2}\right.$ $=0.15$ ). Neither temperature, ration level nor interaction between the 2 variables were found to have an effect on the OL-OW relationship (ANCOVA, all p > 0.05, $\mathrm{n}=$ 350). There was also no significant difference in the OLOW relationship between experimental and field samples (ANCOVA, p >0.05, $\mathrm{n}=470$ ). Therefore, Model (2) was used for all estimations of OW.

\section{Model (3)}

The constants of Model (3) were estimated as $a_{\mathrm{DW}}=$ $-4.439(0.147), b_{\mathrm{DW}}=0.866(0.046), c_{\mathrm{DW}}=0.041(0.002)$ and $d_{\mathrm{DW}}=0.003(0.001)$, where values in brackets are SEs of the estimate. All variables were significantly different from zero (GLM, all $\mathrm{p}<0.05, \mathrm{r}^{2}=0.89$, df $=261$ ), but none of the interactions were significant (GLM, all $\mathrm{p}>0.05, \mathrm{df}=261)$. The model error $\varepsilon_{\text {ind }}$ was distributed normally with homogenous variance $\left(s^{2}=0.11\right)$.

Model (4)

The parameters of Model (4) were estimated to be $a_{\mathrm{OW}}=-3.659(0.062), b_{\mathrm{OW}}=0.544(0.012)$ and $c_{\mathrm{OW}}=0.490$ (0.022), where values in brackets are SEs of the estimate (GLM, all $\mathrm{p}<0.001, \mathrm{r}^{2}=0.74, \mathrm{df}=2253$ ). The DW term was derived from Model (3). The $\ln (\mathrm{DW}) \times \ln (T)$ interaction was not significant ( $p>0.05)$. The residuals were normally distributed with homogenous variance $\left(\mathrm{s}^{2}=\right.$ 0.35). Substituting the DW term of Model (4) with the working equation of Model (3), otolith growth of the experimental samples is described by the model:

$\ln \left(\Delta \mathrm{OW}_{\mathrm{i}} / \Delta t_{\mathrm{i}}\right)=$ 


\section{Increment structure in the field samples}

No changes in increment pattern were found in the pelagic juveniles from the November sample. For the demersal juveniles of the December cruise, an overview of the values of the 3 pattern changes in relation to Day of Year is shown in Fig. 6. For all otoliths with more than one change in increment pattern, the first increment pattern change $\left(D_{\max 1}\right)$ was found to be significantly larger than the subsequent $D_{\max 2}$ (paired $t$-test, $\mathrm{p}<0.001)$. The secondary changes were predominantly associated with the time of thermocline turnover, while there was no relation between $D_{\max 1}$ and date. The corresponding average increment widths decreased significantly between intervals $I_{1}, I_{2}$ and $I_{3}$ (paired $t$-tests, $\mathrm{p}<0.001$ ). Thus, the first change in increment pattern is very distinct from the subsequent, presumably temperature-related, change.

For comparison with published results, the average fish size at $\mathrm{OL}_{1}$ was estimated using the otolith lengthfish length regression of the pooled field samples: $\ln (\mathrm{SL})=a+b \cdot \ln (\mathrm{OL})+c \cdot \ln (\mathrm{OL})^{2}$, where $a=0.182, b=$ -1.776 and $c=7.550\left(\mathrm{df}=119\right.$ and $\mathrm{r}^{2}=0.97$ ). This yielded a presumed settling size of $43.4 \pm 9.4 \mathrm{~mm}$ for the slope and $45.5 \pm 6.1 \mathrm{~mm}$ for the bank. Accordingly, fish size corresponding to $\mathrm{OL}_{2}$ and $\mathrm{OL}_{3}$ were calculated to $59.9 \pm 19.2$ and $97.2 \pm 14.2 \mathrm{~mm}$ for the slope and $60.7 \pm 9.3$ and $79.4 \pm 16.0 \mathrm{~mm}$ for the bank, respectively.

\section{Validation of daily increment formation in the field samples}

On the bank, where fish did not have the option to migrate across a thermocline, and thereby induce a

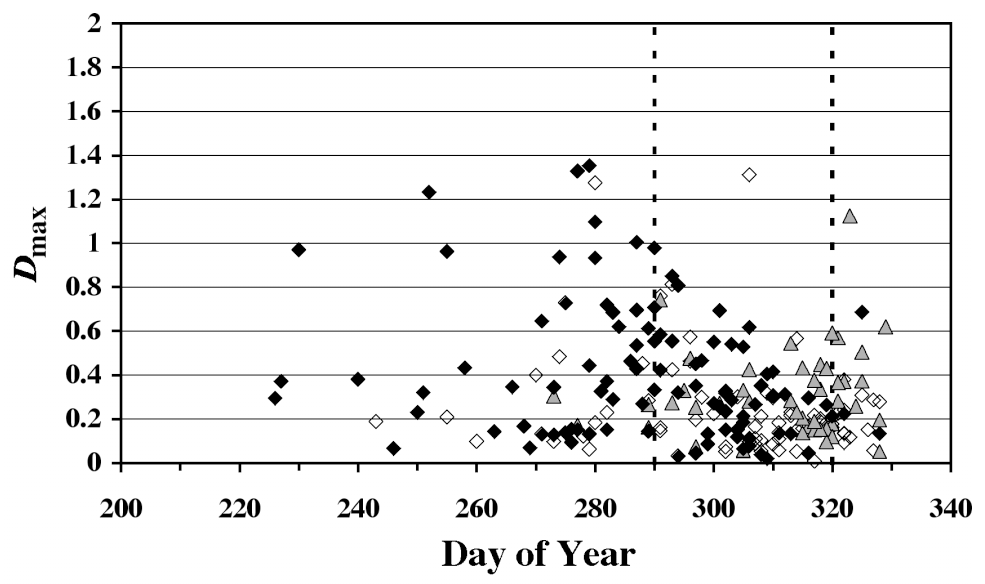

Fig. 6. Gadus morhua. Magnitude of change in increment width, calculated as $D \max _{\mathrm{j}}=$ absolute value of average $\left(\mathrm{IW}_{\mathrm{i}-10}\right.$ to $\left.\mathrm{IW}_{\mathrm{i}}\right)-$ average $\left(\mathrm{IW}_{\mathrm{i}}\right.$ to $\left.\mathrm{IW}_{\mathrm{i}+10}\right)$. Vertical broken lines indicate time of thermocline turnover. $\bullet$ : transition from pelagic to demersal; $\diamond$ : first pattern change in demersal stage; $\Delta$ : second pattern change in demersal stage
Table 1. Gadus morhua. Overview of the comparison of otolith growth rates in the different growth-increment pattern intervals $I_{\mathrm{j}}$. Behaviour patterns are the 3 scenarios with which the model was run: (1) fish stay above thermocline (Surface), (2) fish stay close to seabed (Bottom), and (3) fish undertake daily migrations (Migration). For fish on the bank a non-migratory behaviour in association with the bottom was assumed (No migration). $a=$ proportionality constant of the $\Delta \mathrm{OW}_{\text {est }} / \Delta t_{\mathrm{j}}=a \cdot \Delta \mathrm{OW} / \Delta t_{\mathrm{j}}$ relationship (see 'Materials and methods' for details), $\mathrm{r}^{2}=$ correlation coefficient of this relationship, $\mathrm{n}=$ number of observations and $\mathrm{p}=$ significance $\left(^{*}=0.05,{ }^{* *}=0.01,{ }^{* * *}=0.001\right)$ level of comparison between observed and estimated growth rates (paired $t$-test)

\begin{tabular}{|lclcccc|}
\hline Locality & $I_{\mathrm{j}}$ & Behaviour pattern & $\mathrm{a}$ & $\mathrm{n}$ & $\mathrm{r}^{2}$ & $\mathrm{p}$ \\
\hline Bank & 1 & No migration & 1.108 & 50 & 0.74 & $\mathrm{~ns}$ \\
& 2 & No migration & 0.858 & 30 & 0.94 & ${ }^{*}$ \\
& 3 & No migration & 0.741 & 14 & 0.57 & ${ }^{* * *}$ \\
Slope & 1 & Surface & 1.080 & 50 & 0.63 & $\mathrm{~ns}$ \\
& 2 & Surface & 0.869 & 39 & 0.59 & $\mathrm{~ns}$ \\
& 3 & Surface & 0.721 & 22 & 0.46 & ${ }^{* *}$ \\
& 1 & Migration & 1.114 & 50 & 0.52 & ${ }^{*}$ \\
& 2 & Migration & 1.010 & 39 & 0.61 & $\mathrm{~ns}$ \\
& 3 & Migration & 0.626 & 22 & 0.45 & ${ }^{* * *}$ \\
& 1 & Bottom & 1.230 & 50 & 0.58 & ${ }^{* *}$ \\
& 2 & Bottom & 0.953 & 39 & 0.61 & $\mathrm{~ns}$ \\
& 3 & Bottom & 0.848 & 22 & 0.85 & $\mathrm{~ns}$ \\
\hline
\end{tabular}

subdaily increment structure, observed $\left(\Delta \mathrm{OW} / \mathrm{D} t_{\mathrm{j}}\right)$ and estimated $\left(\Delta \mathrm{OW} \mathrm{W}_{\text {est }} / \Delta t_{\mathrm{j}}\right)$ growth rates did not differ significantly (paired $t$-test, df $=49, \mathrm{p}>0.05$ ) in the first increment interval $I_{1}$, whereas the proportionality constant $a$ of the $\Delta \mathrm{OW}_{\text {est }} / \Delta t_{\mathrm{j}}=a \cdot \Delta \mathrm{OW} / \Delta t_{\mathrm{j}}$ relationship decreases in $I_{2}$ and $I_{3}$ (see Table 1). In all intervals, residuals were evenly scattered around zero, with constant variance. On the slope, no significant differences between observed and expected growth rates were found under the assumptions that juvenile cod stay above the thermocline during $I_{1}$, undertake daily vertical migration in $I_{2}$ and stay close to the bottom in $I_{3}$ (paired $t$-test, df $=49$ in $I_{1}, 38$ in $I_{2}, 21$ in $I_{3}$, all p > 0.05). Under all 3 assumptions the proportionality constant a decreased from $I_{1}$ to $I_{3}$ (see Table 1). The residuals were evenly scattered around zero, with constant variance.

\section{DISCUSSION}

In this study we showed that it is possible to distinguish between different increment patterns in otoliths of juvenile Baltic cod with an objective method based on the difference between the running means of consecutive 
increment widths. Such pattern changes are known to be induced by metamorphosis in a wide range of fish species, with respect to both morphology, e.g. formation of accessory primordia, and suddenly changing growth rates and visual appearance (Lee \& Byun 1996, Modin et al. 1996, Arai et al. 1997). Similar changes in otolith growth have been associated with the transition from pelagic to demersal habitat utilisation (Brothers \& McFarland 1981, Victor 1982), but have mainly been determined by visual census (e.g. Wilson \& McCormick 1997, 1999, see however Victor 1986). In the pelagic juveniles of this study, no change in increment pattern was observed, while the first pattern change in demersal-caught juvenile Baltic cod occurred within a few days at a fish size of 40 to $50 \mathrm{~mm}$, corresponding to the settling size determined by $24 \mathrm{~h}$ trawling studies (Böttcher \& Oeberst 1996, Nielsen et al. 1997) and stomach content analysis (Hüssy et al. 1997, Nielsen et al. 1997). Thus, the first change in increment pattern, from wide to narrow increments, seems to be correlated with settling.

The periodicity of increment formation has traditionally been validated by laboratory experiments. In larval fish this has predominantly been achieved by comparing increment counts with the known age of the fish (e.g. Geffen 1982, Folkvord et al. 1997). In juvenile fish, marking of the otolith prior to release in the wild or rearing of the fish for a known period of time has been the preferred procedure. Such marks may be induced either with chemical reagents, such as oxytetracycline and alizarin complexone (e.g. review in Geffen 1992) or by periodical variation in water temperatures (e.g. Mosegaard \& Titus 1987, Volk et al. 1990, 1994, this study). Neither of these approaches is applicable to the evaluation of increment structures observed in unmarked field samples. For this purpose, an otolith growth model was developed, based on data from laboratory-reared fish, where the hypothesis of daily increment formation was tested and accepted.

The best fit between observed and estimated growth rates indicated that juvenile cod spend most of their time above the thermocline during the pelagic stage $\left(I_{1}\right)$, undertake vertical migrations during the early demersal stage $\left(I_{2}\right)$ and remain associated with the bottom to a higher degree in the late demersal stage $\left(I_{3}\right)$. These results correspond well with previous observations from $24 \mathrm{~h}$ trawl studies on the vertical distribution of juvenile Baltic cod (Böttcher et al. 1998).

Due to the high correlation between observed and estimated otolith growth rates, it was not possible to reject the hypothesis that the observed increments in juvenile Baltic cod otoliths were formed daily. The estimated number of days within the different increment pattern intervals was therefore accepted to be representative of true fish age.
Acknowledgements. Financial support of the University of Copenhagen and the Danish Institute for Fisheries Research is gratefully acknowledged. We thank Skretting a/s Denmark for providing food pellets for the experimental part of this work. The present work has been carried out with financial support from the Commission of the European Communities, Agriculture and Fisheries (AIR and FAIR), specific RTD programme CT98-3959 STORE as a contribution to CT97-3805 SAP. This paper does not necessarily reflect the views of the Commission. Finally, we would like to thank 3 anonymous reviewers for their helpful comments about a previous version of the manuscript.

\section{LITERATURE CITED}

Arai T, Otake T, Tsukamoto K (1997) Drastic changes in otolith microstructure and microchemistry accompanying the onset of metamorphosis in the Japanese eel Anguilla japonica. Mar Ecol Prog Ser 161:17-22

Bergström S, Carlsson B (1994) River runoff to the Baltic Sea: 1950-1990. Ambio 23(4-5):280-287

Böttcher U, Oeberst R (1996) Investigations to the otolithmicrostructure of juvenile Baltic cod in the phase of the settling. ICES CM 1996/J:9

Böttcher U, Oeberst R, Mieske B (1998) Daily vertical migration patterns of Baltic 0-group cod. ICES CM 1998/J:9

Brothers EB (1981) What can otolith microstructure tell us about daily and subdaily events in the early life history of fish? Rapp P-V Réun Cons Int Explor Mer 178:393-394

Brothers EB, McFarland WN (1981) Correlations between otolith microstructure, growth, and life history transitions in newly recruited french grunts [Haemulon flavolineatum (Desmarest), Haemulidae]. Rapp P-V Réun Cons Int Explor Mer 178:369-374

Bryan K (1969) A numerical method for the study of the circulation of the world ocean. J Phys Oceanogr 15: 1312-1324

Campana SE (1983a) Feeding periodicity and the production of daily growth increments in otolith of steelhead trout (Salmo gairdneri) and starry flounder (Platichtys stellatus). Can J Zool 61:1591-1597

Campana SE (1983b) Interactive effects of age and environmental modifiers on the production of daily growth increments in otoliths of plainfin midshipman, Porichthys notatus. Fish Bull 82:165-177

Campana SE, Neilson JD (1982) Daily growth increments in otoliths of starry flounder (Platichthys stellatus) and the influence of some environmental variables in their production. Can J Fish Aquat Sci 39:937-942

Campana SE, Neilson JD (1985) Microstructure of fish otoliths. Can J Fish Aquat Sci 42:1014-1032

Campana SE, Gagné JA, Munro J (1987) Otolith microstructure of larval herring (Clupea harengus): image or reality? Can J Fish Aquat Sci 44:1922-1929

Cox MD (1984) A primitive equation 3-dimensional model of the ocean. Geophysics and Fluid Dynamics Laboratory (GFDL) Ocean Group Technical Report 1, GFDL, Princeton University, Princeton, NJ

Folkvord A, Rukan K, Johannessen A, Moksness E (1997) Early life history of herring larvae in contrasting feeding environments determined by otolith microstructure analysis. J Fish Biol 51:250-263

Gallego A, Heath MR, McKenzie E, Cargill LH (1996) Environmentally induced short-term variability in the growth rates of larval herring. Mar Ecol Prog Ser 137:11-23

Geffen AJ (1982) Otolith ring deposition in relation to growth 
rate in herring (Clupea harrengus) and turbot (Scophthalmus maximus) larvae. Mar Biol 71:317-326

Geffen AJ (1992) Validation of otolith increment deposition rate. In: Stevenson DK, Campana SE (eds) Otolith microstructure examination and analysis. Can Spec Publ Fish Aquat Sci 117:101-113

Gidhagen L (1987) Coastal upwelling in the Baltic Seasatellite and in situ measurements of sea-surface temperatures indicating coastal upwelling. Estuar Coast Shelf Sci 24:449-462

Hüssy K, St. John MA, Böttcher U (1997) Food resource utilization by juvenile Baltic cod Gadus morhua: a mechanism potentially influencing recruitment success at the demersal stage? Mar Ecol Prog Ser 155:199-208

Imsland AK, Nilsen T, Folkvord A (1998) Stochastic simulation of size variation in turbot: possible causes analysed with an individual-based model. J Fish Biol 53:237-258

Lee TW, Byun JS (1996) Microstructural growth in otoliths of conger eel (Conger myriaster) leptocephali during the metamorphic stage. Mar Biol 125:259-268

Lehmann A (1995) A three-dimensional baroclinic eddyresolving model of the Baltic Sea. Tellus 47A:1013-1031

Linkowsky TB, Kowalwska-Pahlke M (1993) Growth of juvenile Baltic cod estimated from daily growth increments in otoliths. ICES CM 1993/J:19

Lough RG, Potter DC (1993) Vertical distribution patterns and diel migrations of larval and juvenile haddock Melanogrammus aeglefinus and Atlantic cod Gadus morhua on Georges Bank. Fish Bull 91:281-303

Marshall SL, Parker SS (1982) Pattern identification in the microstructure of sockeye salmon (Oncorhynchus nerka) otoliths. Can J Fish Aquat Sci 39:542-547

Matthäus W, Franck H (1992) Characteristics of major Baltic inflows - a statistical analysis. Cont Shelf Res 12:1375-1400

Modin J, Fagerholm B, Gunnarsson B, Pihl L (1996) Changes in otolith microstructure at metamorphosis of plaice, Pleuronectes platessa L. ICES J Mar Sci 53:745-748

Mosegaard H, Titus R (1987) Daily growth rates of otoliths in yolk sac fry of two salmonid species at five different temperatures. In: Kallander SO, Farnholm B (eds) Proceedings V Congress of European Ichthyologists, Stockholm. Swedish Museum of Natural History, Stockholm, p 221-227

Neilson JD, Geen GH (1982) Otoliths of chinook salmon (Oncorhynchus tshawytscha): daily growth increments and factors influencing their production. Can J Fish Aquat Sci 39:1340-1347

Neilson JD, Geen GH (1985) Effects of feeding regimes and

Editorial responsibility: Otto Kinne (Editor),

Oldendorf/Luhe, Germany diel temperature cycles on otolith increment formation in juvenile chinook salmon, Oncorhynchus tshawytscha. Fish Bull 83:91-101

Nielsen JR, Lundgren B, Lehman KM (1997) Describing distribution and density patterns of metamorphosed 0- and 1group cod related to hydrographical conditions, physical frontal zones, and bottom topography using hydroacoustic and trawl sampling methods in the central Baltic Sea (preliminary results). ICES CM 1997/S:19

Pannella G (1971) Fish otoliths: daily growth layers and periodical patterns. Science 173:1124-1127

Perry RI, Neilson JD (1988) Vertical distributions and trophic interactions of age-0 Atlantic cod and haddock in mixed and stratified waters of Georges Bank. Mar Ecol Prog Ser 49:199-214

Radtke RL, Dean JM (1982) Increment formation in the otoliths of embryos, larvae, and juveniles of the mummichog, Fundulus heteroclitus. Fish Bull 80:201-215

Semtner AJ (1974) A general circulation model for the World Ocean. University of California, Department of Meteorology Tech Rep 8, Los Angeles

Steffensen E (1980) Daily growth increments observed in otoliths from juvenile East Baltic cod. Dana 1:29-37

Tanaka K, Mugiya Y, Yamada J (1981) Effects of photoperiod and feeding on daily growth patterns in otolith of juvenile Tilapia nilotica. Fish Bull US 79:459-466

Taubert BD, Coble DW (1977) Daily rings in otolith of three species of Lepomis and Tilapia mossambica. J Fish Res Board Can 34:332-340

Victor BC (1982) Daily otolith increments and recruitment in two coral-reef wrasses, Thalassoma bifasciatum and Halichoeres bivittatus. Mar Biol 71:203-208

Victor BC (1986) Delayed metamorphosis with reduced larval growth in a coral reef fish (Thalassoma bifasciatum). Can J Fish Aquat Sci 43:1208-1213

Volk EC, Schroder SL, Fresh KL (1990) Inducement of unique otolith banding patterns as a practical means to massmark juvenile Pacific salmon. Am Fish Soc Symp 7: 203-215

Volk EC, Schroder SL, Grimm JJ (1994) Use of a bar code symbology to produce multiple thermally induced otolith marks. Trans Am Fish Soc 123:811-816

Wilson DT, McCormick MI (1997) Spatial and temporal validation of settlement-marks in the otoliths of tropical reef fishes. Mar Ecol Prog Ser 153:259-271

Wilson DT, McCormick MI (1999) Microstructure of settlement-marks in the otoliths of tropical reef fishes. Mar Biol 134:29-41

Submitted: July 1, 2002; Accepted: July 1, 2003

Proofs received from author(s): August 15, 2003 